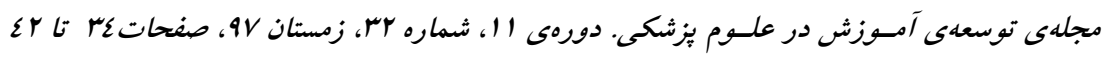

برر سىى رابطه آَاهاهى از حقوق شهروندى اسلامى با منسانى سازمانى مديران كَروههاى

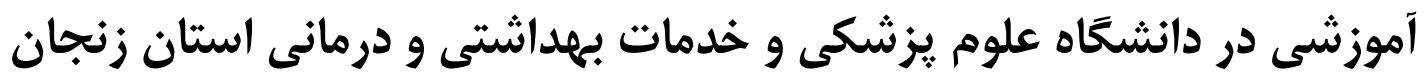

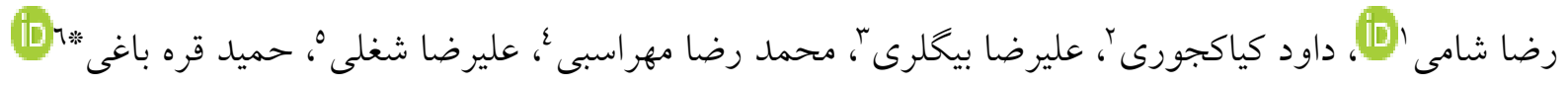

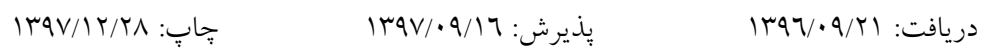

جُكيده زمينه و هدف : هدف ثخوهش حاضر تعيين رابطه بين آكاهى از حقوق شهروندى اسلامى و منسانى (similar-to-me) سازمانى مديران كروههاى

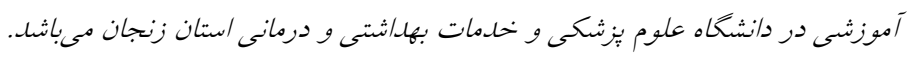

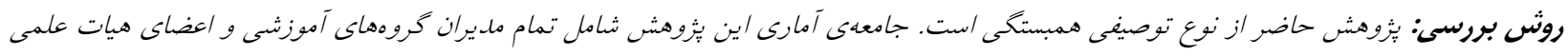

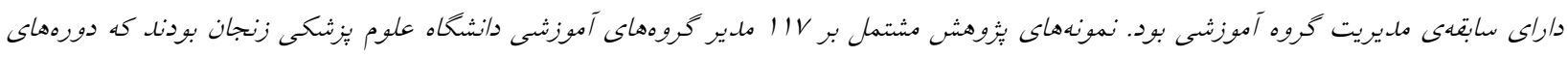

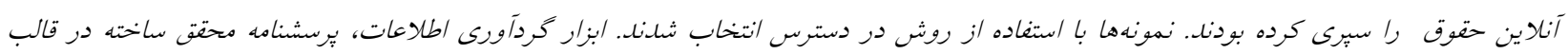

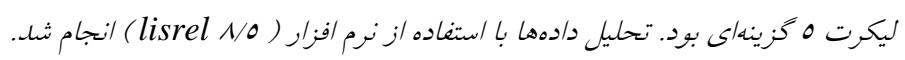

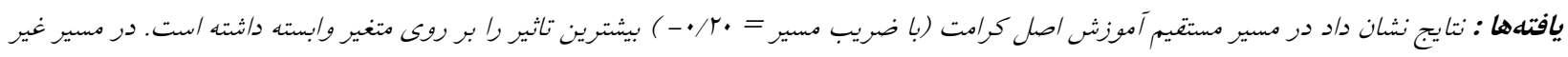

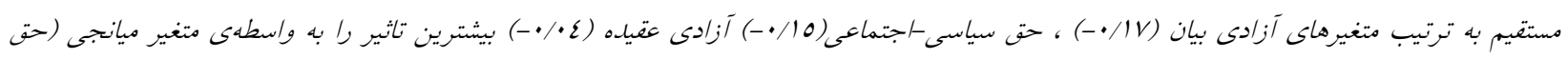

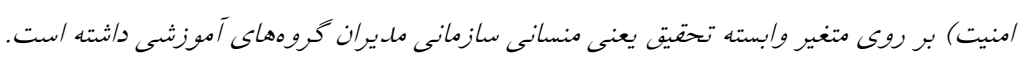

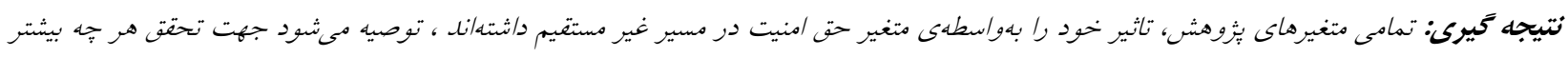

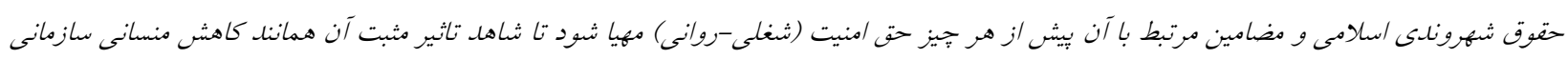
در ملديران كروههاى آموزشى باشيم.

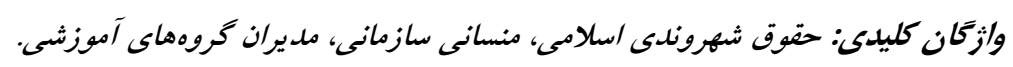
اين مقاله بدين صورت ارجاع داده شود: Shami R, Kia kojouri D, Biglari A, Mehrasbi M, Shoghli A, Gharehbaghi H. Evaluation of Relationship between Awareness of Islamic Citizenship Rights and Organizational Similar-to-me of Education Managers of Zanjan University of Medical Sciences. J Med Educ Dev. 2019; 11 (32) :34-42

1- گروه مديريت دولتى، دانشخاه آزاد اسلامى واحد تهران مركزى، تهران، ايران. ץ- كروه مديريت دولتى، دانشخاه آزاد اسلامى واحد جِالوس، جّالوس، ايران. r- كروه يزشكى مولكولى، دانشكدهى يز شكى، دانشخاه علوم يز شكى زنجان، زنجان، ايران. ع- كروه بهاشت محيط، دانشكدهى بهداشت و بيرايزشكى، دانشخاه علوم يزشكى زنجان، زنجان، ايران. ه- كروه بهاشت و يزشكى اجتماعى، دانشكدهى يزشكى، دانشگاه علوم بزشكى زنجان، زنجان، ايران. 7 - گروه برنامه ريزى و رفاه اجتماعى، دانشكدهى علوم اجتماعى دانشخاه علامه طباطبائى، تهران ،ايران.

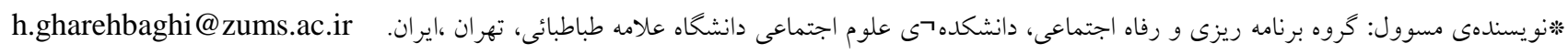


حقوق شهروندى همان حقوق بشر است و تنها عنصرى كه بدان افزوده مىشود، عنصر مسئوليت است كه مجموع حقوق

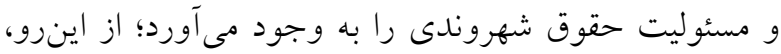
مقايسه حقوق شهروندى اسلامى با حقوق شهروندى

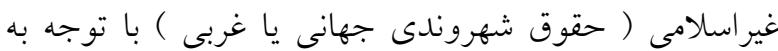
مبانى و جداى از مشتركات آن، داراى فرق هايى مىباشد(0)، مانند اختلاف در نخرش به انسان، اختلاف در ضمانت اجر (sanctions)، اختلاف در سنجش يُشرفت. از نظر اسلام

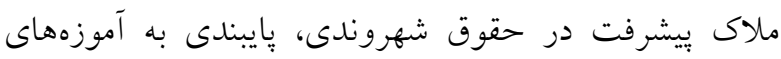

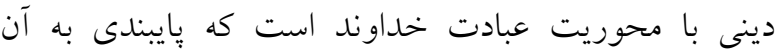

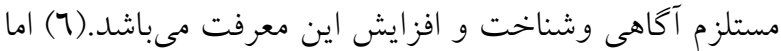
فارغ از اين اختلافات صورى، حقوق بشر اسلامى در موارد فراوانى با حقوق بشر انسانى متناظر است و يا برعكس در

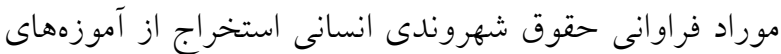
دينى است. اطلاق حقوق شهروندى اسلامى به مجموعهاى از

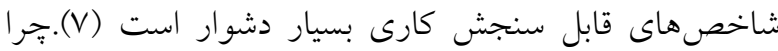

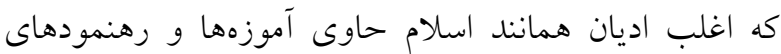

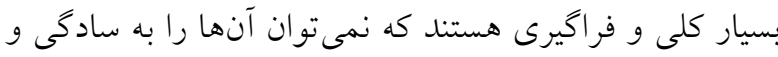
با قاطعيت به جند شاخص محقق ساخت تنزل داد .اما جهت

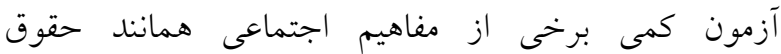
شهروندى لاجرم بايد به تعداد محدودى شاخص استخراج

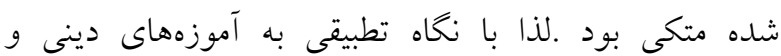
مكتوبات اسلامى مىتوان جند شاخص كلى مانند حق حيات،

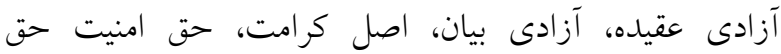

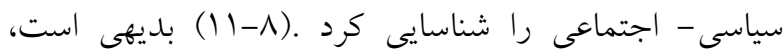
حقوق شهروندى اسلامى، حقوق شهروندى انسانى و يا حقوق بشر بر وجوه مشتركى از حقوق انسانها تاكيد دارند و

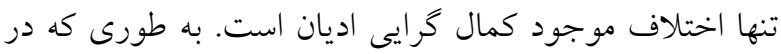

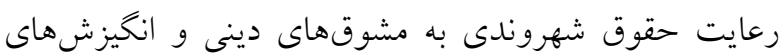
فرا زمينى تاكيد مىشود و تلاش دارد رعايت و عمل به حقوق
حقوق شهروندى دير زمانى است كه در اغلب جوامع توسعه يافته مطرح شده و مباحث زيادى نيز در اين خصوص مطرح و در جريان است(1). اما به رغم تمامى اين تلاشها در

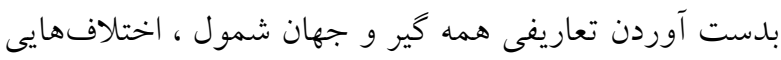
در برخى مباحث و مفاهيم اساسى آن وجود دارد و اين در هرئر شرايطى است كه اغلب كشورهاى اسلامى بر اين باور هستند كه حقوق شهروندى بايد زير مجموعهاى از مبانى دينى بوده و يا لااقل در خصوص شاخصها و مولفهها، از مبانى دينى الهام و تبعيت نمايد. ضرورت به اصطلاح بومى سازى مفاهيم،

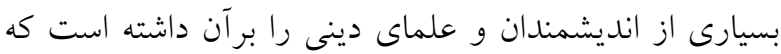
حقوق شهروندى اسلامى را موازى با حقوق متداول در جوامع ديخر مطرح نمايند (Y). مطالعات نشان مىدهد كه اين

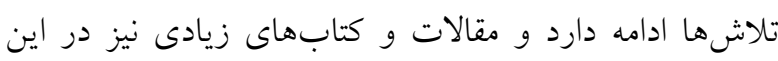
رابطه در ايران و جهان منتشر شده است. به رغم اين تلاشها تاكنون تحقيقات كمى و عملياتى بسيار محدودى در اين رابطه انجام شده است. لذا در اين ئزوهش محققان سعى دارند كه برخى از مولفههاى حقوق شهروندى اسلامى را با يكى از مفاهيم علمى و اكادميك مديريت سازمانها، با عنوان منسانى سازمانى را در سطح مديران گروههاى آموزشى و با روش وش

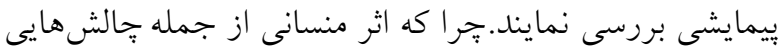
است كه به شدت بر ثبات مديريتى در قريب به به اتفاق

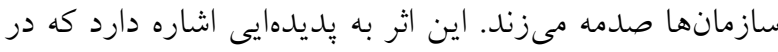

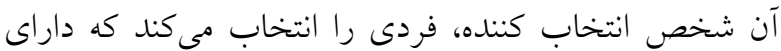

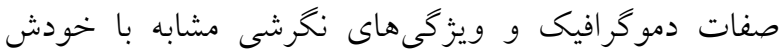
باشد. لذا به نظر مىرسد با اشاعهى مفاهيم حقوق شهروندى

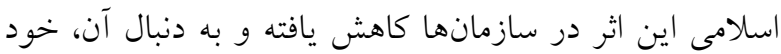
اين مفهوم موجبات رشد حقوق شهروندى اسلامى در سازمانهايى شود كه سعى دارند با ارزشهاى بومى و دينى سازمانها را اداره نمايند.(r, ع) انديشمندان معتقد هستند كه 
شخصى نياز داريم كه كارى براى ما انجام دهد بايستى همانند

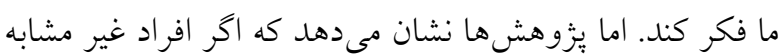

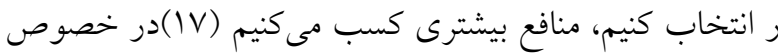
ارتباط كلى دو متغير حقوق شهروندى و كاهش منسان سازمانى در اين تحقيق بايد كفت، اعتقاد به حقوق شهروندى

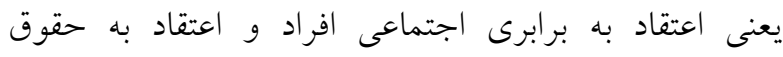

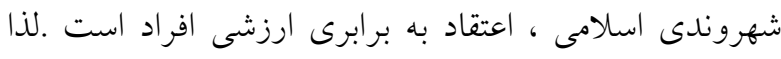

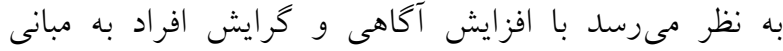

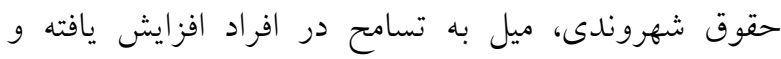
شخص ترغيب مىشوند تا افرادى را كه ديدكاههاى متفاوتى دئى

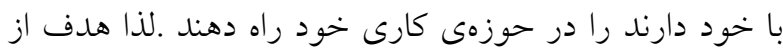
اين يزوهش تعيين رابطه بين آكاهى از حقوق شهروندى اسلامى و منسانى (similar-to-me) سازمانى مدير ان كروههاى

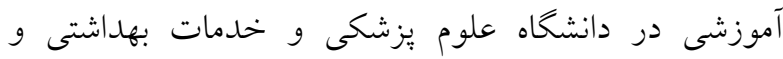
درمانى استان زنجان (ZUMS) مى باشد.

\section{روش بررسى}

اين مطالعه از نوع توصيفى - همبستكى مىباشد. جامعهى

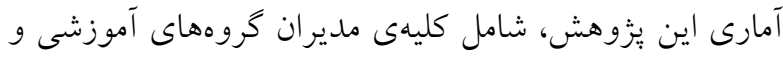

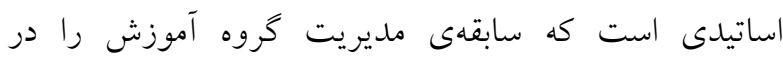

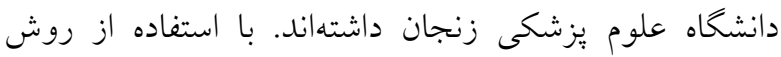

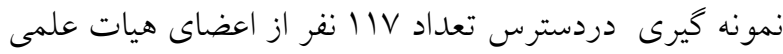
كه سابقهى مديريت گروه آموزشى را داشتهاند و هم:خنين

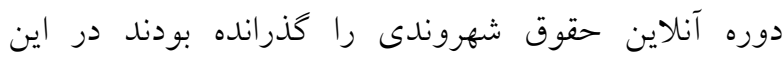

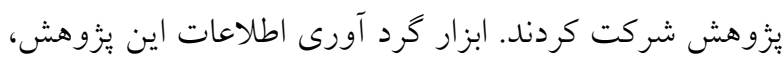
يرسشنامه محقق ساخته مى باشد. كه در آن متغير منسانى

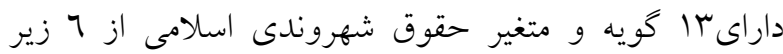

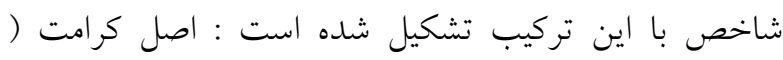

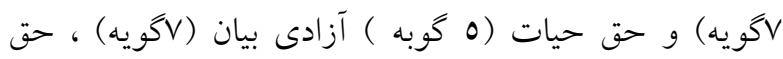

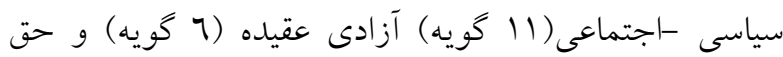

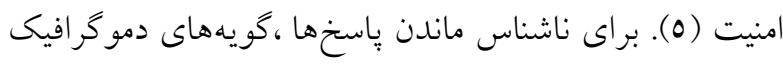

شهروندى را در اذهـان درونى نمايـــ و از سوى ديخر با

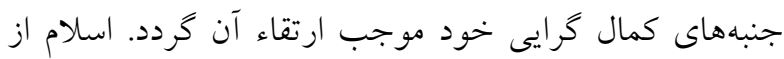

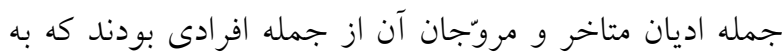
لحاظ تاريخى در دورههايى از زندگى خود از برخى از حقوق

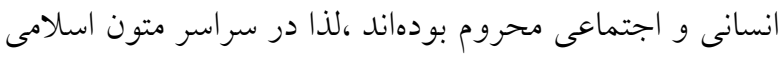

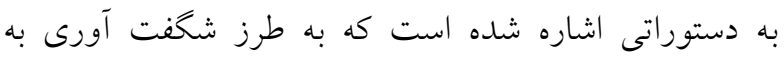
صراحت - به اصلاح - به حقوق شهروندى افراد اشاره شده

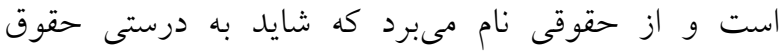
شهروندى نام كذارى شده است. آنجه در اين تحقيق بهعنوان حقوق شهروندى اسلامى ياد شده است حقوق شهروندى تطبيقى با تم دينى و يا از زاويه ديد اسلامى است كه رعايت اين حقوق به الزام دينى - اعتقادى و عدم رعايت اين حقوق را با عقوبت دينى بيوند خورده است. تغييرات مديريتى موجود در همه سازمانها اغلب مديران را وا ميدارد معاونين و

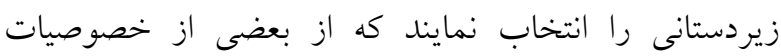
زمينهاى مانند: مذهب، جناح سياسى، تحصيلات، افكار،

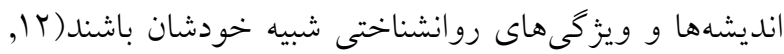
س|).رعايت حقوق شهروندى اسلامى در سازمان با مفهوم

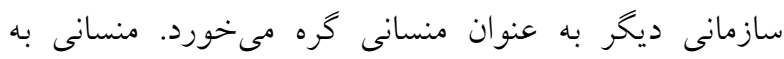
شرايطى اشاره دارد كه افراد در يكى تلاش عامدانه ،افراد شبيه خود را در برخى خصوصيات اساسى زمينه كزينش مى كنيد

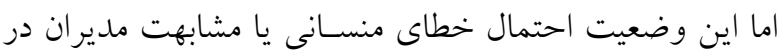
تصميمهاى بيجيده را افزايش داده است (عا, 10). يافتههاى

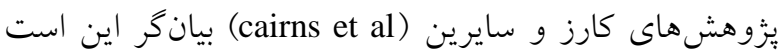

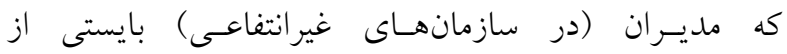
سوكيرىهاى ناشى از منسانى در فرآيند انتخاب يرهيز

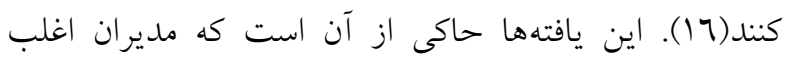

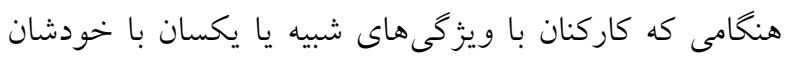
استخدام نمى كنند، مطلوبيت بالاترى كسب مى كنند و كاركرد

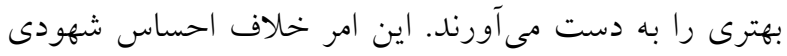

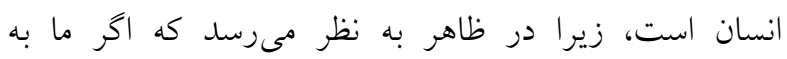


r نفر از اساتيد گروه روانشناسى، ץ نفر از مديران ارشد

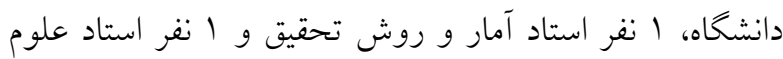
اسلامى) قرار گرفت .يس از انجام نظر خواهى و دريافت

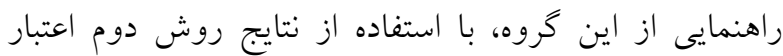

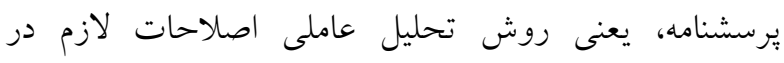
يرسشنامه تركيبى حاضر انجام كرفت. محاسبه پيايايى

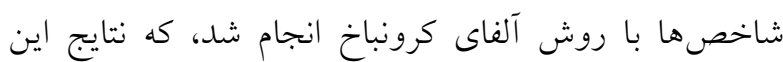
آزمونها در جدول آمده آمده است.
( جنسيت، وضعيت تاهل، سن، شغل) در انتهاى برسشنامه

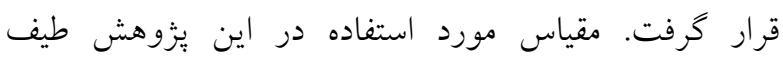
ليكرت بينج درجهاى (1=كاملا مخالفم ،r=مخالفم،r=نظرى 0. ندارم، ع=موافقم، = = كاملا موافقم) است. همجنين يرسشنامه با هدف سنجش وّايايى و روايى در بين مديران

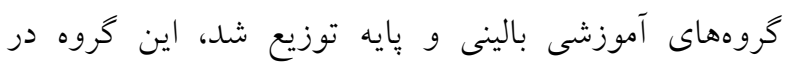

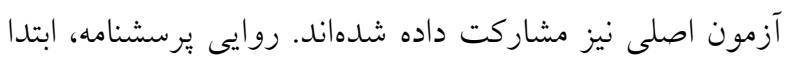
با روش اعتبار محتوا انجام شد به اين صورت كه بِرسشنامه مذكور جهت تاييد محتوا علمى در اختيار V نقر خبره (شامل

جدول ا: آزمون روايى و بايايى برسشنامه منسانى سازمانى و حقوق شهروندى اسلامى توسط آزمون آلفاى كرونباخ و تحليل عامل

\begin{tabular}{|c|c|c|c|c|c|}
\hline معنادارى & درجهى & آزمون كرويت بارتلت & ارزش كايزر-ماير - & مقدار آلفا كرونباخ & نام شاخص \\
\hline$\cdot / \cdots$ & $\varepsilon r$ & OrN/TII & $\cdot N \cdot 1$ & $\cdot / 1491$ & منسانى سازمانى \\
\hline$\cdot / \cdots$ & ry & $T r V / \wedge \varepsilon r$ &.$/ 719$ & $\cdot / 1997$ & حق حيات \\
\hline$\cdot / \cdots$ & iv & $r M N / N \cdot q$ &.$/ 7 V$ &.$/ 9 \varepsilon r$ & آزادى عقيده \\
\hline$\cdot / \cdots$ & ru & $0 . \varepsilon \pi T V$ & $\cdot N \cdot 1$ & $\cdot / 110$ & آزادى بيان \\
\hline$\cdot \cdots$ & 1. & oVI/IVT & . &.$/ 90 \mathrm{r}$ & حق امنيت \\
\hline$\cdot / \cdots$ & ir & 9r7/rOT & $\cdot N V V$ & $\cdot / \wedge \varepsilon 0$ & اصل كرامت \\
\hline$\cdot \cdots$ & r) & $991 / 2 \cdot 0$ & - /7ro & $\cdot / \wedge 7$. & حق سياسى -اجتماعى \\
\hline
\end{tabular}

قوىترين و دقيقترين آزمون تست نرمال مىباشد، مورد

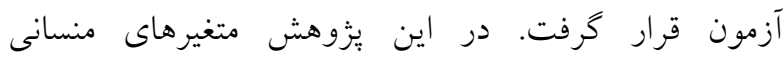

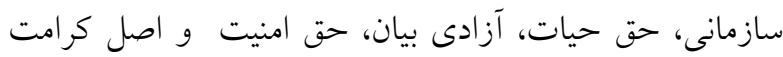
داراى توزيع نرمال بود و براى متغير آزادى عقيده (17) (palues= تبديل دادهها به كار گرفته شد. روش تبديل به كار گرفته شده

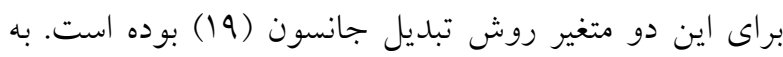

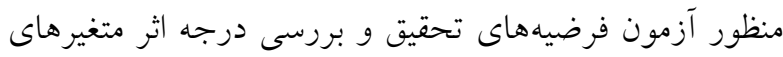

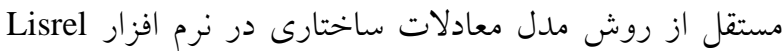
استفاده كرديد. در اين روش معيار يذيرش معندادارى ضرايب
روش تحليل اطلاعات روش مدل معادلات ساختارى (تيبٍ

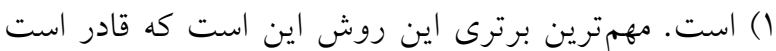

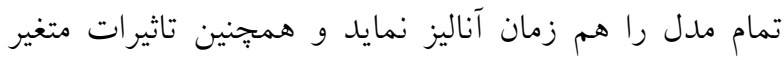
واسط را نيز در اجزاء مدل محاسبه مىكند. براى استفاده از

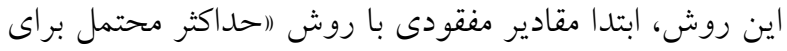
دادههاى مفقود) با استفاده از تكنيك ( Expectation (Maximization

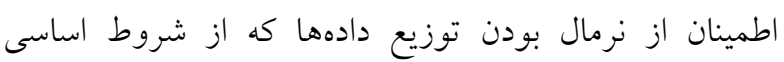

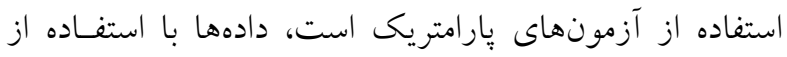

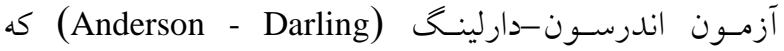




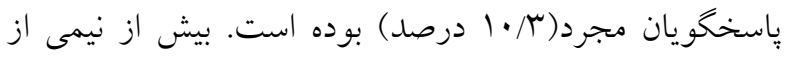

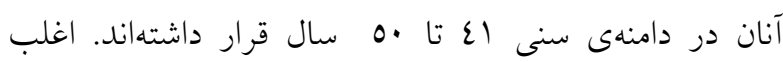

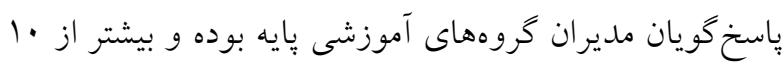

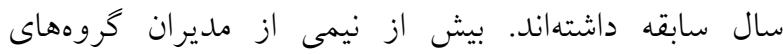

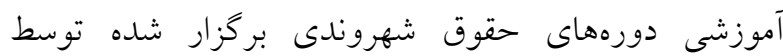

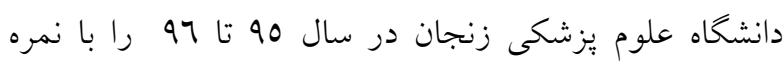

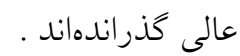

>T> 1/97 ( مسير، قرار داشتن آنها در آستانه مقدار بحرانى (1/97 ) - است.

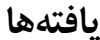
يافتهها نشان داد كه مردان با (V9/0 درصد) تقريبا ب برابر بيشتر از زنان (Y/0) در اين تحقيق شركت كردهاند، همجنين

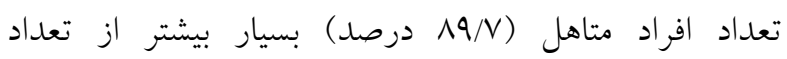

\begin{tabular}{|c|c|c|c|}
\hline درصد & فراوانى & زير گروه & متغير \\
\hline$v 9 / 0$ & $9 \pi$ & مرد & \multirow[b]{2}{*}{ جنسيت } \\
\hline$r \cdot / 0$ & $T \varepsilon$ & زن & \\
\hline $0 / 9$ & v & آTا:ع & \multirow{3}{*}{ سن } \\
\hline or & $\pi r$ & $0 . \mid 21$ & \\
\hline$\varepsilon$ & $\varepsilon \wedge$ & •0 سال به بالا & \\
\hline $19 / \mathrm{V}$ & 1.0 & متاهل & \multirow{2}{*}{ وضعيت تاهل } \\
\hline $1 \cdot / r$ & ir & مجرد & \\
\hline $11 / 7$ & $\varepsilon$ & بالينى & \multirow[b]{2}{*}{ خروه آموزشى } \\
\hline$\Delta r / r$ & vi & بايه & \\
\hline$|V /|$ & $r$. & 1-1· سال & \multirow[b]{2}{*}{ تجربه كارى } \\
\hline$\Lambda \Gamma / \Lambda$ & $9 V$ & بيشتر از ·ل سال & \\
\hline$v \cdot / 1$ & NT & بله & \multirow{2}{*}{ كذراندن دورههاى حقوق شهروندى با نمرهى } \\
\hline$r q / 9$ & rr & خير & \\
\hline
\end{tabular}

حالت مىتوان به تاييد يا رد فرضيههاى يُزوهش يرداخت. همان كونه كه مشاهده مى شود مقدار

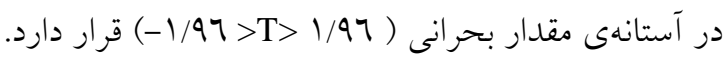

شكل ا مدل نهايى اين يزوهش را نشان مىدهد، كه با توجه

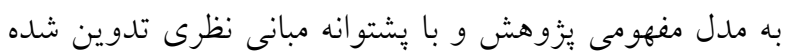

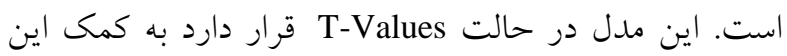




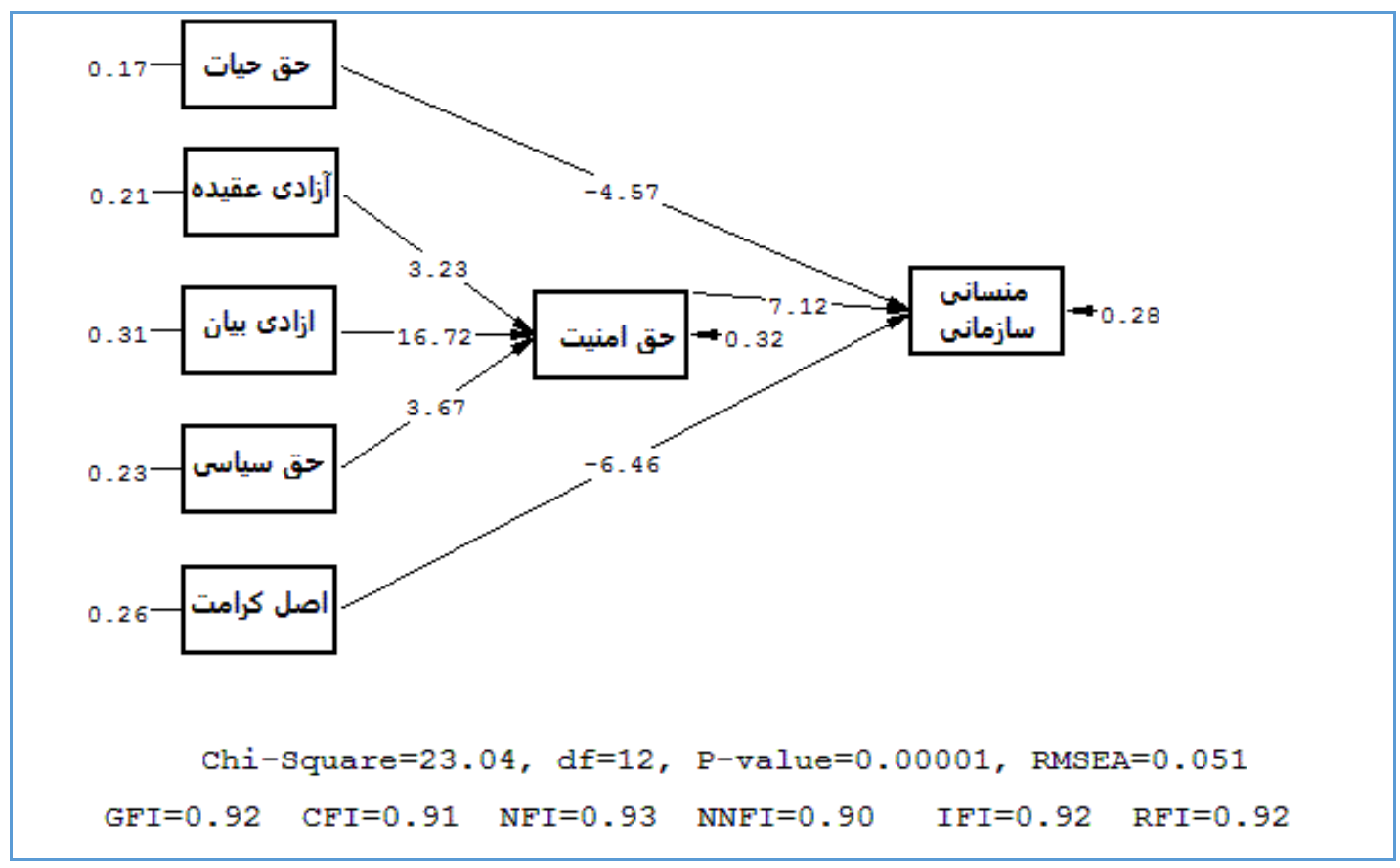

شكل 1: مدل معادلات ساختارى بُزوهش در حالت معنادارى

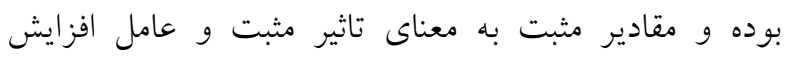

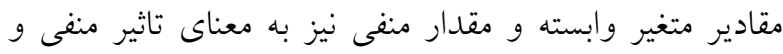
موجب كاهش مقادير متغير وابسته مى گردد.
شكل r، حالت استاندارد مدل مفروض را نمايش مىدهد، در

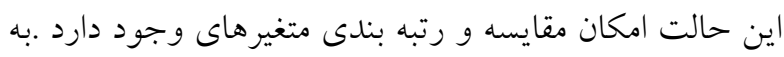
اين صورت كه مقدار بيشتر ضريب مسير به معناى تاثير بيشتر

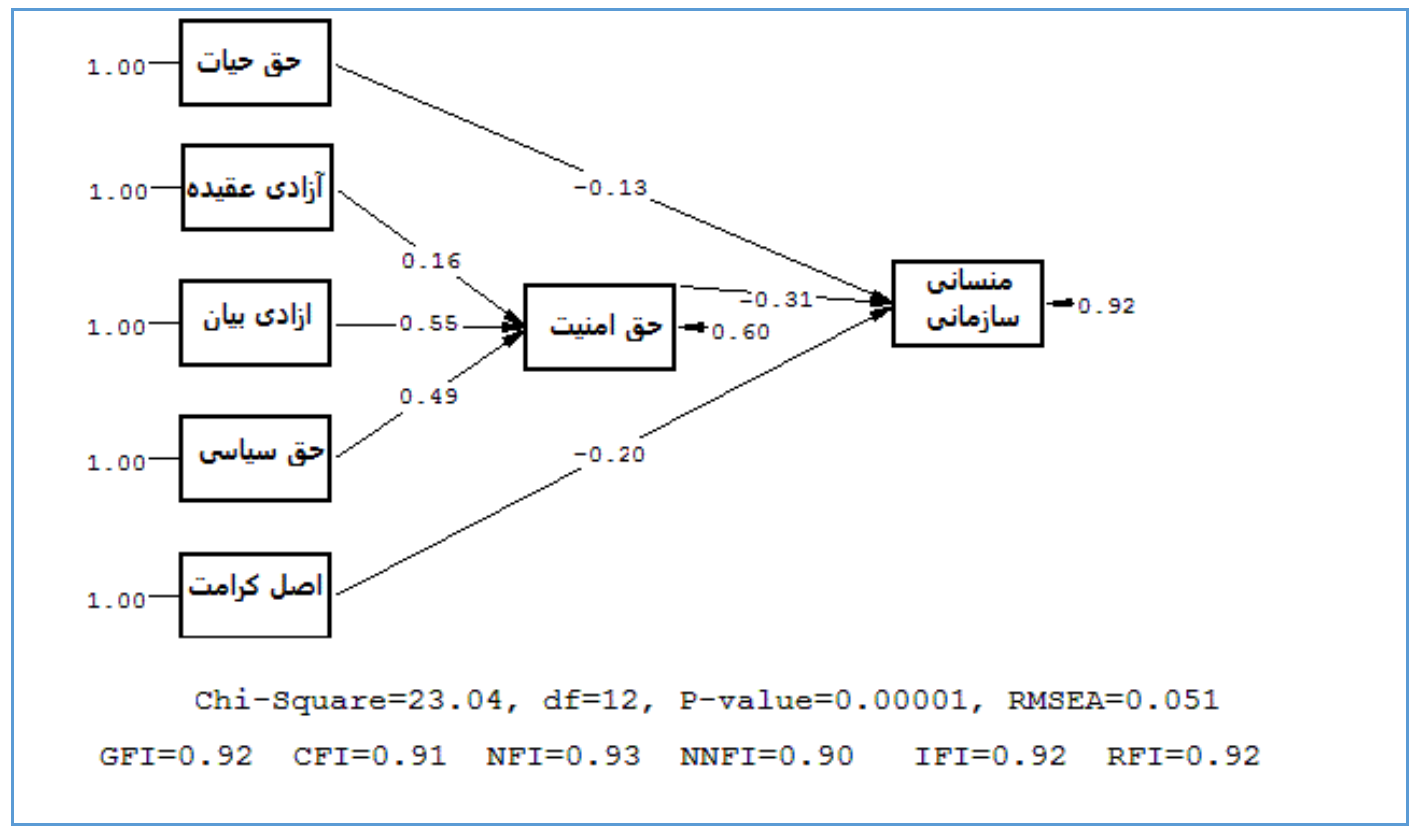

شكل ؟ : مدل معادلات ساختارى برُوهش در حالت مقادير استاندارد 
طبق اطلاعات مدل (1 و r)مقدار شاخصهاى GFI=

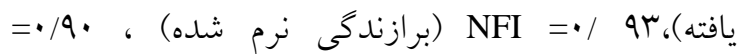

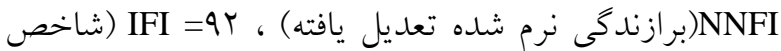
برا زندگى فزاينده ) و RFI =•/9r (شاخص برازش نسبى)

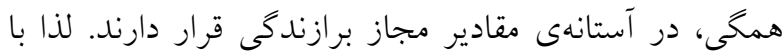

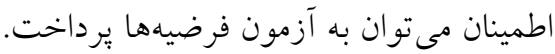

اولين معيار قضاوت برازش مدلهاى( () و (Y)، مقدار كاى

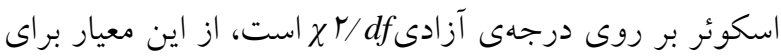

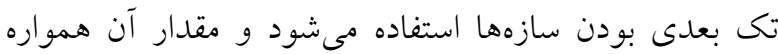
بايد كمتر از ب باشد .مقدار اين شاخص براى مدل

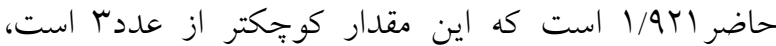

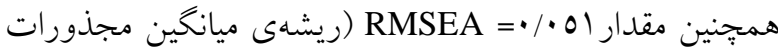

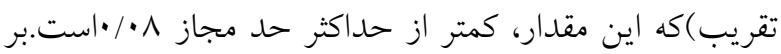

جدول r: خلاصه مقادير، علائم و متغيرهاى مكنون مدل معادلات ساختارى بثزوهش

\begin{tabular}{|c|c|c|c|c|c|}
\hline وضعيت & مقدار ضريب مسير & $\begin{array}{l}\text { T- مقدار } \\
\text { values }\end{array}$ & متغيرهاى وابسته & متغير هاى & متغيرهاى مستقل \\
\hline تاييد شد & $-\bullet / 1 \Gamma^{*}$ & $-\varepsilon / 07$ & منسانى سازمانى & - & حق حيات \\
\hline تاييد شد & $(\cdot / 17 *-\cdot / 1)=-\cdot / \cdot \Sigma^{* * *}$ & T/K & منسانى سازمانى & حق امنيت & آزادى عقيده \\
\hline تاييد شد & $(\cdot / 00 *-\cdot / \Gamma 1)=-\cdot / 1 V^{* * * * * *}$ & $17 / V T$ & منسانى سازمانى & حق امنيت & آزادى بيان \\
\hline تاييد شد & $(\cdot / 29 *-\cdot / \mu 1)=-\cdot / 10^{* * * *}$ & $r / 7 V$ & منسانى سازمانى & حق امنيت & حق سياسى -اجتماعى \\
\hline تاييد شد & $-\cdot / r^{*} * * *$ & $-7 / \varepsilon 7$ & منسانى سازماني & - & اصل كرامت \\
\hline
\end{tabular}

نتايج اين تحقق نشان داد كه در مسير مستقيم، اصل كرامت انسانى بيشترين تاثير را برروى كاهش منسانى سازمانى داشته است طى سالهاى اخير در سازمانهاى دولتى مقوله تكريم

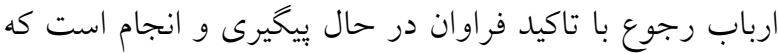
نشان دهندهى اهميت ويزه آن براى دست اندركاران امور

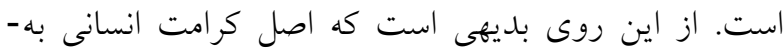
عنوان يك مفهوم كلى اما آشنا در سازمانهاى امروز ايران جزء متغيرهاى بسيار تاثير كذار باشد كه نه تنها به افراد برون

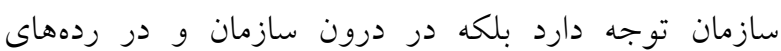
مديريتى بالاتر نيز نوعى تسامح و تساهل و در نتيجه كاهش

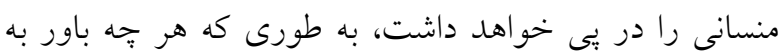

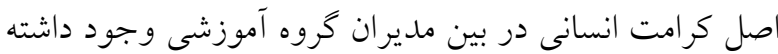
باشد به طبع آنان گرايش بيشترى به تعامل و استفاده از نيروى
بحث

در اين بزووهش رابطهى حقوق شهروندى اسلامى با منسانى

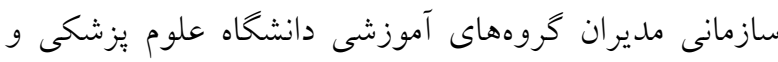
خدمات بهاشتى و درمانى استان زنجان مورد بررسى قرار كرفت و اثرات مستقيم و غيرمستقيم آنها با يكديخر و با باتئ

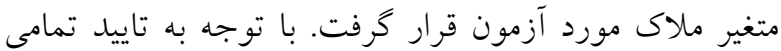
فرضيه هاى موجود، مدل مفهومى ثيزوهش حاضر مدل مناسبى براى بيش بينى اثر حقوق شهروندى اسلامى و زير شاخصهاى آن بر كاهش منسانى سازمانى مديران كروه آموزشى لئى است .نتايج يزوهش حاضر بيانگ وجود رابطه منفى ومعنادار

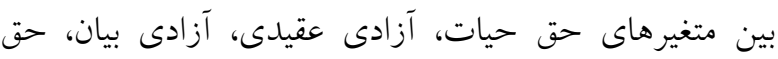
سياسى -اجتماعى، اصل كرامت و منسانى سازمانى در بين

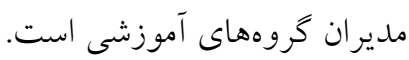


يردازى و شناسايى ابعاد شاخصهاى بخش دموكراسى

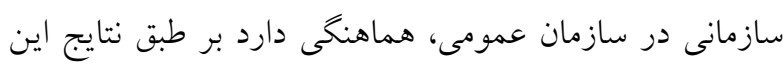

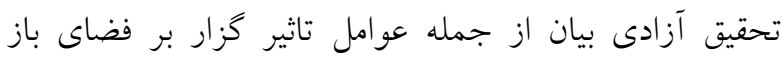
سازمانى است. حق سياسى - اجتماعى دومين متغير تاثير كذارى است كه اثرات خود را در سايهى حق امنيت بر روى إنى

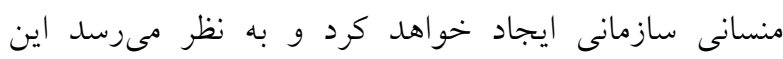

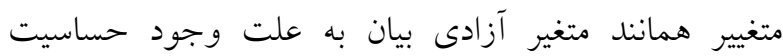

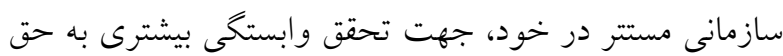

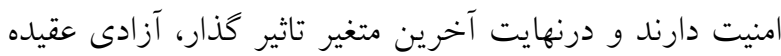
است. اين متغير نيز همانند دو متغير قبلى بهواسطه متغير حق

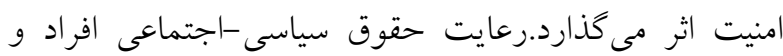

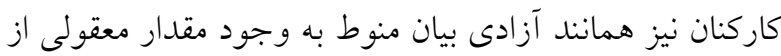
امنيت در سازمان است. مديران غير منسان افرادى هستند كه از كرايشات سياسى متنوعترى در سازمان بهره مىبرند. به مديه

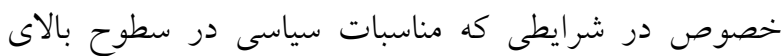

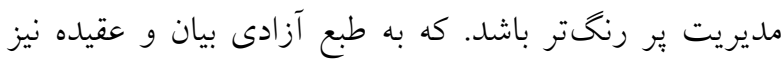

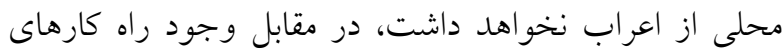
مناسب جهت ترويج شاخصهاى كاربردى حقوق شهروندى

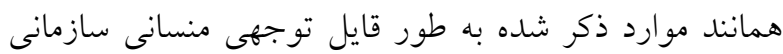
را كاهش و ترويج تسامح را در بي خواهد داشت اين يافته با نتايج محمد خانباشى و غلامرضا بستان منش هماهنكى دارد. اين تحقيق بر اين اعتقاد است كه، نيروى انسانى نهادهاى

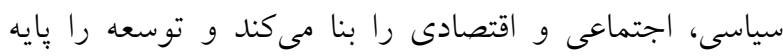

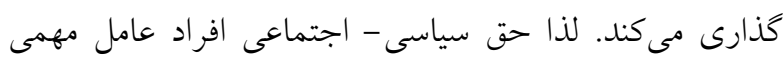
در نهادينه سازى دمكراسى سازمانى و كاهش منسانى سازمانى

( است . ( ) ( )

\section{نتيجه كيرى}

نتايج اين تحقيق نشان مىدهد آكاهى از حقوق شهروندى

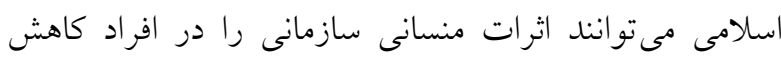
دهد اين كاهش با دخالت مستقيم متغير امنيت در سازمان قابل
افراد ديخر با كرايشات و زمينهى ذهنى متفاوت خواهند

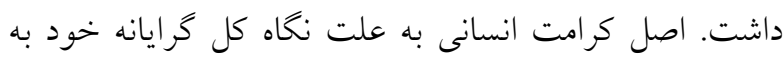
انسانها فارغ از زمينهى ذهنى، دين، جنسيت، زبان و ....، كزينش سليقهاى و بسته افراد و سبكهاى بسته مديريتى

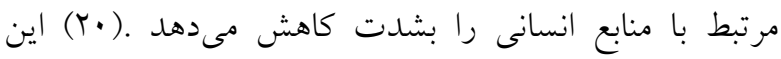

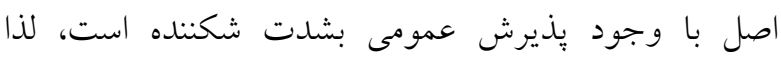

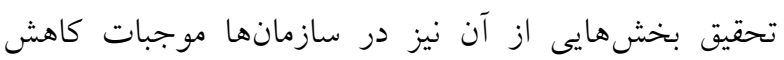
منسانى سازمانى را فراهم خواهد كرد و اين توجه به مسئله در خصوص مديران گروههاى آموزشى ،ارزش اين تاثير كذارى

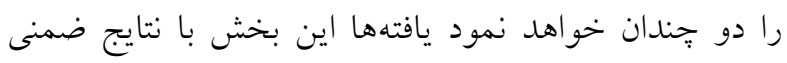

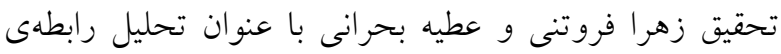

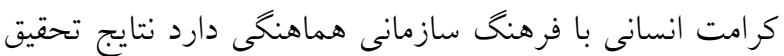

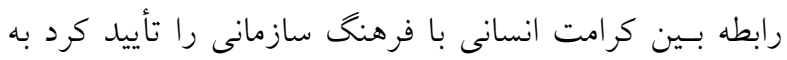
عبارتى هر قدر جايخـاه كرامـت انسـانى در دانشخاه مورد

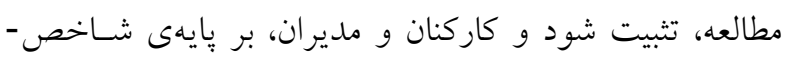
هاى كرامـت انسـانى رفتـار نمايند، ابعاد فرهنخ سازمانى نيز تقويت خواهد شد(Y)). اصل حق حيات دومين متغير تاثير كذار است به طورى كه باور به اين اصل موجب كاهش

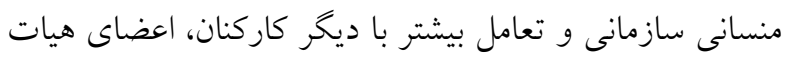

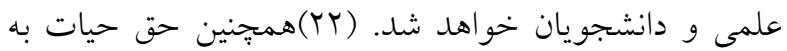
مسوولان و مديران خروههاى آموزشى ياد آورى مىنماييد كه

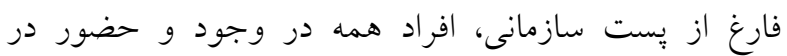
سازمان و ساختار آموزشى برابر هستند نمونه مشابه بى بشمارى در آموزمى اسلامى به صراحت به اين مسئله تاكيد كرده است.

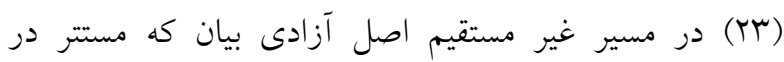
آموزههاى اسلامى و مستخرج از متون اسلامى است، بهـ واسطهى متغير حق امنيت موجب كاهش منسانى سازمانى

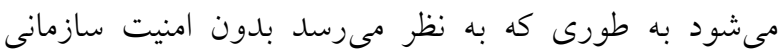

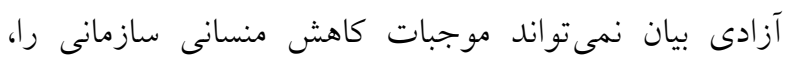
دستكم در بين مديران گروههاى آموزشى فراهم نمايد اين يافته با نتايج تحقيق رضا زارع اكبر و ديخران با عنوان مفهوم 


$$
\begin{aligned}
& \text { تقدير و تشكر } \\
& \text { اين مقاله مستخرج از طرح تحقيقاتى مصوب دري در دانشگاه }
\end{aligned}
$$

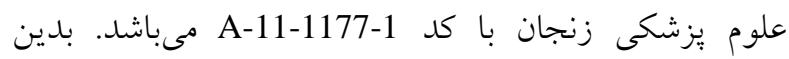

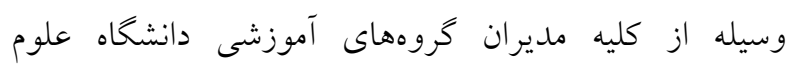

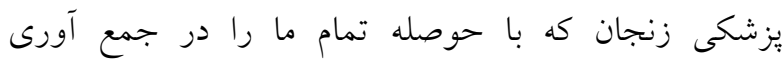

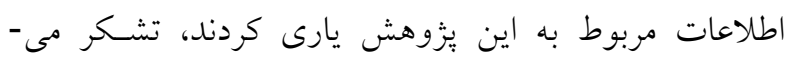

$$
\begin{aligned}
& \text { نماييم. }
\end{aligned}
$$

\section{References}

1- Raminmehr H, HADIZADEH MA, Ahmadi I. Study the relationship between organizational justice perception and organizational citizenship behavior. 2010.

2- Mosavian H. The glimpse to the 8th part Religious foundations of Imam Khomeini -RahWith the Citizenship Rights Approach National Congress of Imam Khomeini's Cultural and Social Thoughts. 2011;1(28):10.

3- Portahmasb S. The rights and education of citizenship in Nahj al-Balaghah. Alavi Research Center. 2012;2:1-23.

4- Amini M. Individual rights of non-Muslim citizens in Islamic society. Quarterly journal of Habal al-Matin. 2013;3(3):140-65.

5- Sayaed Ali F. Components of Citizenship Rights from the View Point of Imam Ali (PBUH). Political Research In Islamic World. 2014;4(2):47-72.

6- Javid MJ. Nature or Human Nature Areas for the Limit of Relativity in Human Rights. Journal of Public Law Research. 2016;18(52):59-85.

7- Hbibzahe M, Others. Human Dignity in the Constitution of the Islamic Republic of Iran. Comparative Law Researches. 2008;11(4):52-82.

8- Habibzadeh T, Farajpour AA. Human Dignity And Reliance Of Human Rights And Citizen's Rights Enshrined In The Constitution of The

$$
\begin{aligned}
& \text { تحقيق است بهطورى كه بدون امنيت اغلب متغيرهاى حقوق }
\end{aligned}
$$

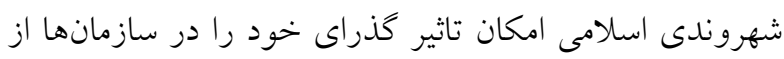

$$
\begin{aligned}
& \text { دست مىدهند. مهمترين محدوديت اين تحقيق كمى سازى } \\
& \text { مفهوم حقوق شهروندى اسلامى و تدوين برسشنامه معتبر در }
\end{aligned}
$$

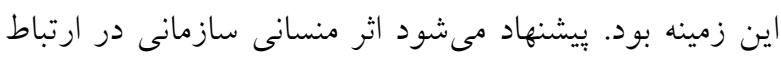

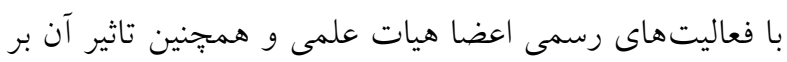

$$
\begin{aligned}
& \text { روى دانشجويان مورد تحقيق قرار گيرد. }
\end{aligned}
$$

Islamic Republic of Iran On Human Dignity. 2016.

9- Mirtorabi S. Islam's view on freedom of opinion and expression. Comprehensive Human Sciences Portal. 2016;4(11):115-27.

10- Niknejad A. Islam's viewonfreedomof opinion andexpression.RavaghAndishe.2004;18:7-26.

11- Watt WM, Montgomery W, Watt Wm. The formative period of Islamic thought: University Press; 1973.

12- Iqtidar H. Tolerance and Tolerance in Islamic Political Thoughts. Islamic studies. 2005;63:155.

13- Dutton E, Lynn R. Intelligence and Religious and Political Differences Among Members of the US Academic Elite. Interdisciplinary Journal of Research on Religion. 2014;10.

14- Fine BJ. Introversion-extraversion and motor vehicle driver behavior. Perceptual and Motor Skills. 1963;16(1):95-100.

15- Barrett R, Mayson S. Human resource management in growing small firms. Journal of Small Business and Enterprise Development. 2007;14(2):307-20.

16- Sears GJ, Rowe PM. A personality-based similar-to-me effect in the employment interview: Conscientiousness, affect-versus competencemediated interpretations, and the role of job relevance. Canadian Journal of Behavioural Science/Revue canadienne des sciences du comportement. 2003;35(1):13. 
17- Mares P, Mares P. Borderline: Australia's treatment of refugees and asylum seekers: Springer; 2001.

18- Lomax RG, Schumacker RE. A beginner's guide to structural equation modeling: psychology press; 2004.

19- Bryman A, Cramer D. Quantitative data analysis with minitab: a guide for social scientists: Psychology Press; 1996.

20- Salehi HR. Human dignity from the viewpoint of Iranian law. Journal of bioethical inquiry. 2013;10(2):135-6.
21- St-Pierre I, Holmes D. The relationship between organizational justice and workplace aggression. Journal of advanced nursing. 2010;66(5):1169-82.

22- Noe RA, Hollenbeck JR, Gerhart B, Wright PM. Human resource management: Gaining a competitive advantage: McGraw-Hill Education New York, NY; 2017.

23- Tung RL. Strategic management of human resources in the multinational enterprise. Human resource management. 1984;23(2):129-43. 